\title{
6 \\ Informal Labour, Local Citizens and the Tokyo Electric Fukushima Daiichi Nuclear Crisis: Responses to Neoliberal Disaster Management
}

\section{Adam Broinowski}

Nuclear workers are important as sentinels for a broader epidemic of radiation related diseases that may affect the general population. ${ }^{1}$

We live with contradictions everyday. ${ }^{2}$

\section{Introduction}

The ongoing disaster at the Fukushima Daiichi nuclear power station (FDNPS), operated by Tokyo Electric Power Company (TEPCO), since 11 March 2011 can be recognised as part of a global phenomenon that has been in development over some time. This disaster occurred within a social and political shift that began in the mid-1970s and that became

1 Paul Jobin, 'Radiation Protection after the Fukushima Nuclear Disaster 3.11', The Journal of Ohara Institute for Social Research, August 658 (2013): 3 (14-30).

2 Anonymous, Association Franco-Japonaise (ASUKA), Témoignages No.1 [Statements by Fukushima genpatsu kokuso-dan] (2014): 6. For a copy contact: www.asuka-association.org/contact/. 
more acute in the early 1990s in Japan with the downturn of economic growth and greater deregulation and financialisation in the global economy. After 40 years of corporate fealty in return for lifetime contracts guaranteed by corporate unions, as tariff protections were lifted further and the workforce was increasingly casualised, those most acutely affected by a weakening welfare regime were irregular day labourers, or what we might call 'informal labour'.

During this period, many day labourers evacuated rented rooms (doya どや) and left the various yoseba (urban day labour market よせば, or lit. 'meeting place') to take up communal tent living in parks and on riverbanks, where they were increasingly victimised. With independent unions having long been rendered powerless, growing numbers of unemployed, unskilled and precarious youths (freeters フリーター) alongside older, vulnerable and homeless day labourers (these groups together comprising roughly 38 per cent of the workforce in 2015) ${ }^{3}$ found themselves not only lacking insurance or industrial protection but also in many cases basic living needs. With increasing deindustrialisation and capital flight, regular public outbursts of frustration and anger from these groups have manifested since the Osaka riots of $1992 .{ }^{4}$

As Mike Davis observed, an un(der)protected informal sector in cities and industrial zones around the world occurs where there is a dilution or absence of labour rights and is characterised by 'semi-feudal kickbacks, bribes, tribal or gang loyalties and ethnic exclusion'. ${ }^{5}$ Whether on a construction site, on the pavement, or in a domestic employment situation, informal labour comprises a surplus or reserve army of mercenary, irregular or precarious workers who pay off their debt for the opportunity to work through the availability of their cheap labour power.

3 Jeff Kingston, 'How to become an Activist: Start as a Japanese Part-Timer', Bloomberg, 29 May 2015, www.bloomberg.com/news/articles/2014-05-29/how-to-become-an-activist-start-asa-japanese-part-timer. Accessed 16 July 2015.

4 The Osaka riots of 1992 are known as the 'anti-unemployment riots' in the Kamagasaki day labour centre in Nishinari ward. Day labourers who could no longer pay the rent demonstrated on the streets in protest. As distinct from the 1990 riots in the same location, which were specifically targeted against corrupt ties of the Nishinari police with a yakuza group, a large number of youths joined the day labourers in 1992 to protest against unemployment. See M. Yang, K. Haraguchi and T. Sakurada, 'The Urban Working-Class Culture of Riot in Osaka and Los Angeles: Toward a Comparative History', in B. Fraser ed., Marxism and Urban Culture (New York: Lexington Books, 2014), 230-31.

$5 \quad$ Mike Davis, Planet of the Slums (London and New York: Verso, 2006), 185. 
In this chapter, first I outline the conditions of irregular workers at nuclear power plants and the excess burden they have borne with the rise of nuclear labour in Japan since the 1970s. I then turn to post-3.11 conditions experienced by residents in radiation-contaminated areas. Contextualising these conditions within the genealogy of radiodosimetry standards, I seek to show, through personal interviews and localised responses, how those who are regularly exposed to radiation from Fukushima Daiichi are now confronting problems similar to those faced by informal nuclear labour for decades in Japan. This analysis shows how, after 40 years or more of environmental movements as discussed in Chapter Four, the struggle continues to find viable solutions to the systemic production of the intertwined problems of environmental crises and labour exploitation, and suggests how potential alternative directions for affected populations may lie in their mutual combination.

\section{Conditions for Informal Labour Employed in Nuclear Power Stations}

The phenomenon of assembling and recruiting a relatively unskilled labour pool at the cheapest rate possible is typical in nearly all of Japan's large-scale modern industrial projects in the 20th century. As early as the late 19th century, however, non-criminal homeless men were recruited for such projects, whether forced, coerced or voluntarily from the major day-labourer (biyatoi rōdosha 日雇い労働者) sites (yoseba) established in Sanya (Tokyo), Kotobuki (Yokohama), Kamagasaki (Osaka) and Sasashima (Nagoya). In pre-World War II and wartime Japan, yakuza tehaishi (手配師 labour recruiters) operated forced labour camps known as takobeya (たこ部屋 octopus rooms) for Korean and Chinese labourers who had been transported to work mainly in coal mines and on construction sites. ${ }^{6}$

The Dodge Line policy of 1949 stemmed rapid inflation by stabilising the yen, drastically curtailing government spending in the public sector, directly affecting education, public works and services such as the Japan National Railway (JNR), and cutting export subsidies for small businesses while expanding loans to big business. ${ }^{7}$ Aimed at replacing the 'production

6 Brett Nee, 'Sanya: Japan's internal colony', Bulletin of Concerned Asian Scholars 6, no. 3 (1974): 14.

7 Sugita Yoneyuki, Pitfall or Panacaea: The Irony of US Power in the Occupation of Japan 1945-1952 (New York: Routledge, 2003), 52-68. 
first' with an 'export first' approach, this policy of economic liberalisation increased unemployment, lifted tariff protection and reconfigured the zaibatsu (財閥 industrial and financial business conglomerates during the Meiji, Taisho and Showa periods) as conglomerates without holding companies. The ranks of unemployed labour, including zainichi (在日 resident in Japan) Korean and Chinese, swelled in urban ghettos. During the 1950s, the new labour unions were crushed, and, with the return of the big conglomerates, agriculture increasingly faced growing competition from cheap American food imports. Urban labourers were rendered more pliable and many farmers and fisher people were forced from traditional livelihoods and communities to do seasonal work (dekasegi 出稼ぎ) on large-scale industrial or construction projects. ${ }^{8}$ As the ties to their village communities and practices weakened or were lost, many became seminomadic, drifting from site to site and randomly collecting in yoseba. Like the shanty town or reservation in the colonised sectors of third world/ decolonising countries as observed by Frantz Fanon, these were akin to the renewed 'disreputable places inhabited by disreputable people ... [where] you die anywhere from anything ... this world divided in two, is inhabited by different species'?

In the 1960s and 1970s, with the closure of coal mines, as reliance on coal-fired power was replaced by petroleum, gas and nuclear-based energy generation, informal labour was in demand for the construction of tankers and ore carriers in shipyards fitted with new technologies and on projects such as the national Shinkansen and expressways, the 1964 Olympics and 1970 'Japan World Exposition', and nuclear power stations. Day labourers and irregular workers were vital in this period for the supply of vulnerable and flexible cheap 'unskilled' labour for menial, dirty and dangerous jobs (garbage collection, morgue work, work with animal carcasses, work involving toxic industrial materials etc.).

In the labour employment structure, the parent company (moto-uke 元 請け) employs a subcontracting company (shita-uke 下請け), which employs another subcontractor (mago-uke 孫請け) that relies on labour brokers (tehaishilninpu-dashi 手配師／人夫出し), who are often yakuzaconnected, to guarantee a certain number of workers per day. This nodal structure ensures the parent company penetration to the bottom social

8 Funamoto Shūji, Damatte notare jinuna Funamoto Shüji ikoshū [Don't Die Silently by the Roadside: Posthumous Writings of Funamoto Shūji] (Tokyo: Renga Shobo Shinsha, 1985), 199-200.

9 Frantz Fanon, The Wretched of the Earth (New York: Grove Press, 2004), 4-5. 
layers while reducing their liability for the costs of labour power (accidents, health insurance, safety standards) and maintains responsiveness to the violent logic of supply and demand. Primary and secondary contractors receive money from parent companies like TEPCO to cover workers' salaries and expenses, special danger allowances and bonuses. By employing tehaishi who operate in a liminal zone of under-regulation, they hire cheaply, rapidly, under minimal conditions and seemingly without a direct duty of care.

The rapid build of nuclear power stations was planned in the 1960s by a consortium of major investment banks, electric utilities and construction companies and/or industry manufacturers (Mitsubishi, Tōshiba, Hitachi, Sumitomo, etc.), and was carried out in the 1970s, with increased momentum in response to the oil crisis of 1974-76. Through an intensive 'regional development' program of rural industrialisation from the early 1970s, politically disempowered communities were targeted as potential cheap labour as their environs were designated as sites for nuclear projects by investment capital. In a combination of regulatory capture and economic dependency, utilities moved in to provide employment opportunities to communities while the same communities steadily lost control over their resources and subsistence economies. In the process, they lost political agency as their political representatives often received corporate and state inducements for these projects. As TEPCO owns the electricity distribution system in Fukushima Prefecture, which includes hydroelectric and thermal power stations as well as nuclear, and is a major employer and investor in Fukushima Prefecture, ${ }^{10}$ it has considerable sway in the political process as well as over electricity bills.

By the early 1980s, irregular workers came to comprise nearly 90 per cent of all nuclear workers. ${ }^{11}$ As nuclear reactors grow increasingly contaminated and corroded by radiation over time, informal labour became fodder for regular maintenance, cleaning, repairing and/or venting and refuelling of these nuclear reactors to reduce exposures to permanent company employees such as scientists and engineers. As the

10 Toshihiro Okuyama, 'Radiation Doses 4 Times Larger for 'Outside Workers' at Nuclear Plants, Asahi Shimbun, 26 July 2012, ajw.asahi.com/article/0311disaster/fukushima/AJ201207260071 (subscription only).

11 Eighty-eight per cent of 83,000 workers in Japan's nuclear sector and 89 per cent of 10,303 workers at Fukushima Daiichi are in subcontracting service positions. See Editors, 'Radiation doses 4 times larger for "outside workers" at nuclear plants', Asahi Shimbun, 26 July 2012, ajw.asahi.com/ article/0311disaster/fukushima/AJ201207260071. Accessed 14 January 2015. 
power station must be halted during the maintenance period, this period equates to a lack of production and profitability and is kept to a bare minimum by the operators, an approach that led to a litany of safety oversights and accidents.

Although provided less training, informal nuclear workers are paid higher over a shorter employment period than regular workers, whose insurance is taken out of their wage. Sworn to secrecy, ${ }^{12}$ after a superficial safety education drill, they are sent into highly contaminated, hot and wet labyrinthine areas. Their work includes scrubbing contaminated areas, installing shields to reduce exposure for skilled workers, decontaminating and repairing pipes and tanks, welding, transporting contaminated materials and waste, washing contaminated uniforms and tools, removing filters and clearing garbage, inspecting gauges in high-level areas, dispersing chemicals over nuclear waste piles, pouring high-level liquid waste into drums and mopping up waste water. Although radioprotection regulations have been tightened in the last decade, working conditions for irregular workers have not necessarily improved and, without sufficient information about radiation danger, they can still be exposed to over 1 millisievert $(\mathrm{mSv})$ of external radiation within minutes in high concentration areas and accumulate large amounts of internal radiation. ${ }^{13}$

Since 3.11, invoking the International Commission on Radiological Protection's (ICRPs) often-used ALARA (as low as reasonably allowable) principle to justify this regulatory contingency, the state also raised nuclear workers' limits from no more than $50 \mathrm{mSv}$ per year $(\mathrm{mSv} / \mathrm{y})$ and $100 \mathrm{mSv} / 5$ years to $250 \mathrm{mSv} / \mathrm{y}$ to deal with emergency conditions, and determined that there would be no follow-up health treatment for those exposed to doses below $50 \mathrm{mSv} / \mathrm{y}$, while TEPCO decided to not record radiation levels below $2 \mathrm{mSv} / \mathrm{y}$ in the misplaced justification that the effects would be negligible. In December 2011, 'cold shutdown' was (erroneously) declared and the workers' limit was returned to 100 $\mathrm{mSv} / 5$ years. It will likely be raised again as the government expedites decommissioning to meet its estimated completion by $2030-2050 .{ }^{14}$

12 Kazumi Takaki, 'Listen to Their Silent Cry: The Devastated Lives of Japanese Nuclear Power Plant Workers Employed by Subcontractors or Labour-brokering Companies', Bulletin of Social Medicine 31, no. 1 (2014): 10.

13 Yuki Tanaka, 'Nuclear Power Plant Gypsies in High-tech Society', Bulletin of Concerned Asian Scholars, 18, no. 1 (1986): 12. See also Takaki, 'Listen to Their Silent Cry', 9.

14 For perspective, the estimated completion of decommissioning of Chernobyl is 2086. 
Although very few regular workers' cumulative doses exceeded $20 \mathrm{mSv} / \mathrm{y}$ in any year prior to 3.11 , by June 2015 the official number rose to $6,642^{15}$ with doses of irregular nuclear workers often un(der)counted.

In a fast-track 40-year plan to decommission Fukushima Daiichi (i.e. removing the cores and dismantling the plant), as of August 2015 roughly 45,000 irregular workers ('front-line' workers, or 'nuclear gypsies') had been assembled at the J-Village Iwaki-Naraha soccer stadium before entering the sites. As well as jobs at the power stations, they work on decontamination and construction sites throughout the prefecture, which include those designated for the 2020 Olympics, a new school in Futaba (the town nearest to FDNPS), a large centre for radiation monitoring, a large research and training institute for reactor decommissioning, and a giant sea wall for tsunami prevention (see also Chapter Five). Yakuzalinked labour brokers (tehaishilninpu-dashi), eager to profit from the post3.11 decommissioning budget (conservatively estimated at $\$ 150$ billion), use social media and oral contracts to recruit these workers from the most vulnerable populations for 'clean up' work. ${ }^{16}$ In this customary cascade of diluted responsibility, their original wage and conditions are skimmed or cut away (pinhane sareta ピンハネされた) by contractors (roughly 733 companies) so that some irregular workers receive as little as 6,000 yen per day and only a very small fraction of the 10,000 yen per day in danger money promised by the Ministry of the Environment (MoE) and TEPCO. ${ }^{17}$

Irregular workers' oral contracts with tehaishi are often illegal or dangerous, and are sometimes imposed on workers through threats or use of force. ${ }^{18}$ In addition, the day labourer may become indebted to tehaishi for housing and/or loans for lifestyle dependencies (i.e. gambling, drugs, prostitution). As products of structural discrimination, itinerant and/or

15 Editors, 'Fukushima daiichi genshiryoku hatsudensho sagyōsha no hibaku senryōen no hibaku se ni tsuite', TEPCO, 31 July 2015, www.tepco.co.jp/cc/press/betu15_j/images/150731j0604.pdf. Accessed 1 August 2015.

16 See Hiroko Tabuchi, 'Unskilled Recruited for Fukushima Duty', The Age, 18 March 2014, www. theage.com.au/world/unskilled-recruited-for-fukushima-duty-20140318-hvk08.html; Saito Mari and Antoni Slodowski, 'Japan's Homeless Recruited for Murky Fukushima Clean-up', Reuters, www. reuters.com/article/us-fukushima-workers-idusbre9bt00520131230.

17 Michael Okwu, 'Gangsters and "Slaves": The People Cleaning Up Fukushima', Al Jazeera America, 8 January 2014, america.aljazeera.com/watch/shows/america-tonight/america-tonightblog/2014/1/7/fukushima-cleanupworkerssubcontractors.html.

18 Editor, 'Yajuku rōdōsha no genpatsu hibakusha no jittai o tekisuto shite itadakimashita', Sanya Blog - Yajuku-sha shitsugyō sha undō hōkoku, 15 April 2011, san-ya.at.webry.info/201103/ article_11.html. Accessed 19 January 2016. 
irregular workers who are already socially isolated may find it difficult to build support networks, whether through marriage, family or solid friendships. Obligated within a semi-legal economy and stripped of rights and protections, each worker is pitted against the other, young and old, stronger and weaker, individual and family man, for basic survival.

Over the past 40 years, poor monitoring and record-keeping has meant that many former nuclear workers who develop leukaemia and other illnesses have been denied government compensation due to their lawyers' inability to prove the etiological link between their disease and employment. For example, the death of Yoshida Masao (58), the Fukushima Daiichi manager who was among the 'Fukushima 50' who remained at the plant to manage the nuclear meltdowns in their critical phase and who developed oesophagal cancer in 2013, was not recognised by TEPCO as related to radiation exposure from Fukushima Daiichi as the cancer was deemed to have developed too quickly after the initial accident.

Irregular nuclear workers have commonly relied on permanent employees to monitor, record and calibrate their doses. Denied sufficient information about radiation exposure risks, and preferring not to jeopardise their contracts and provoke physical intimidation if they complain about their conditions, many collude with company officers (who record their accumulated doses) to camouflage and underestimate their dose rates (particularly for internal doses). This allows them to extend their time and contracts at nuclear plants before they are deemed to have reached (or exceeded) the maximum annual dose limit $(50 \mathrm{mSv} / \mathrm{y}) .{ }^{19}$ When a nuclear worker is diagnosed with abnormalities in a routine check-up, some subcontractors may falsify nuclear workers' passbooks. ${ }^{20}$ Despite the long lives of internalised radionuclides, it has been customary either not to measure this properly and/or to simply reset the dose record at the end of each financial year. ${ }^{21}$ While protective clothing and procedures have grown more stringent for nuclear workers, especially after some workers died and fell ill from heat-related causes, irregular workers remain

19 On methods of dosimetry camouflage see Paul Jobin, 'Radiation Protection After the Fukushima Nuclear Disaster 3.11', The Journal of Ohara Institute for Social Research 658 (August 2013): 9.

20 Jobin, 'Radiation Protection', 9.

21 In the 1980s, it was standard practice at the Tsuruga plant of the Japan Atomic Power Company (JAPC) to reset accumulated doses to zero on four days of every month. See Tanaka Yuki, 'Nuclear Power Plant Gypsies', 9. 
far less protected. ${ }^{22}$ At Fukushima Daiichi, where crews are overworked and understaffed, irregular workers often commit errors leading to cases of serious injury and large leaks of radioactive materials into the environment. This is further compounded by the lack of understanding or recognition of chronic illnesses in either permanent or irregular nuclear workers. This has sometimes led to poorly explained deaths of nuclear workers. ${ }^{23}$

In October 2015, a welder in his late 30s and father of three from KitaKyushu became the first worker in four years to be awarded workers' insurance payments (medical costs and loss of income for temporary disability) while three more cases remained undecided. $\mathrm{He}$ was diagnosed with acute myelogenous leukaemia after having accumulated $19.8 \mathrm{mSv} / \mathrm{y}$ from exposure to a radiation leak and one year's work at Fukushima Daiichi (Reactors 3 and 4) and the Genkai nuclear plant (Kyushu) (both of which use MOX fuel). ${ }^{24}$ While compensation was recognised under nuclear workers' compensation insurance legislation (1976), the Health Ministry maintained that a causal link between illness and employment remains to be scientifically proven. After the delayed report by TEPCO of 1,973 workers exposed to over $100 \mathrm{mSv} / \mathrm{y}$ by mid-2013, by August 2015 21,000 of the 45,000 irregular workers had been exposed to over $5 \mathrm{mSv} / \mathrm{y}$ and 9,000 workers to over $20 \mathrm{mSv} / \mathrm{y}^{25}$ TEPCO and the central government would certainly be worried about a spike in compensation claims.

Without a proper health regime, the permanent damage incurred by irregular nuclear workers far outweighs the value of their cheap labour power. With their use as filters as they move to each plant, as nuclear

22 Kazumi Takaki, 'Listen to their Silent Cry', 10.

23 See, for example, Fukushima Daiichi genshiryoku hatsudensho no jökyō ni tsuite, 30 July 2016, TEPCO, www.tepco.co.jp/press/report/2016/1314410_8693.html.

24 Mixed-Oxide fuel (MOX) combines uranium (U238) and plutonium (Pu 239-240) in nuclear fission. The plutonium component makes the fuel even more toxic as well as producing longer-lived waste than with uranium fuel.

25 Yuri Oiwa, 'Ministry Recognizes Link between Fukushima Nuclear Worker's Leukemia and Radiation Exposure for 1st Time', Asahi Shimbun, 20 October 2015, ajw.asahi.com/ article/0311disaster/fukushima/AJ201510200086. Since the time of writing, this article has been made unavailable online. For verification, an online mirror link can be found at: www.fukushimais-still-news.com/2015/10/worker-cancer-case-confirmed-2.html. It is worth recalling that in 2013 TEPCO, after an earlier underestimation of 'only 178' workers, had finally admitted that 1,973 workers had been exposed to over $100 \mathrm{mSv} / \mathrm{y}$. See 'Nearly 2000 at Fukushima No. 1 Face Higher Thyroid Cancer Risk', Japan Times, www.japantimes.co.jp/news/2013/07/19/national/1973fukushima-plant-workers-show-higher-risk-for-thyroid-cancer/\#.V9ff_LXgwXg. 
workers grow older and sicker they become less able to commodify their labour and are unlikely to receive proper treatment and/or compensation (due to insufficient data and high radiation safety limits among other things). Although the endless production of labour willing to take on this dangerous work and the devolution of responsibility and ambiguity around radiation health effects are used to justify the continuation of these practices, if workers are knowingly placed in harmful conditions the employer is in breach of a duty of care under the Labour Standards Law. As byproducts of a discriminatory industrial labour system, these irregular nuclear workers and their families, like many elsewhere, are deprived of basic rights to health and well-being. As one labourer stated in relation to Fukushima Daiichi: 'TEPCO is God. The main contractors are kings, and we are slaves'. ${ }^{26}$ In short, Fukushima Daiichi clearly illustrates the social reproduction, exploitation and disposability of informal labour, in the state protection of capital, corporations and their assets.

\section{Conditions for Residents of Post-3.11 Radiation-Affected Areas}

For roughly 30 years, the exclusion zone around Chernobyl has been set at 30 kilometres. Between 1 and $5 \mathrm{mSv} / \mathrm{y}$ is the assisted evacuation level and mandatory evacuation is $5 \mathrm{mSv} / \mathrm{y}$ and above. Unlike the approach adopted for Chernobyl, which was to achieve containment (a sarcophagus was built in eight months) and permanent resettlement of 350,000 people, the government and TEPCO have adopted a 'dilution' approachto widely disperse and redistribute ('share') radioactive materials and waste and decontaminate residential areas. To date, this has permitted the permanent release through venting, dumping and incinerating of radioactive materials into the air, land, water and sea, and circulation in the food chain and recycled materials on a daily basis since March 2011.

Over the first few days at Fukushima Daiichi nuclear power station, severity (International Nuclear Event Scale) levels were steadily raised from level 3 to level 5 to level 7 , and the mandatory evacuation zone was gradually expanded from 10 to 30 kilometres. On 16 March 2011, readings in Aizu-Wakamatsu Middle School (100 kilometres from FDNPS) in Fukushima Prefecture returned 2.57 microSv/h (microsieverts

26 Okwu, 'Gangsters and "Slaves"'. 
per hour), ${ }^{27}$ and Kōriyama (60 kilometres) recordings returned 3.6-3.9 microSv/h. Inside people's homes in Kōriyama, levels were between 1.5 and $2.0 \mathrm{microSv} / \mathrm{h}$ and $8.2 \mathrm{microSv} / \mathrm{h}$ in the downpipes. ${ }^{28}$ This data was made public only three months later. On 6 April, schools in Fukushima Prefecture were reopened. As the boundaries, legal limits and information were gradually altered, populations were urged to return to work. At the same time the legal safety level for mandatory evacuation for the public (radiation safety level 1972) was raised from 1 to $20 \mathrm{mSv} / \mathrm{y},{ }^{29}$ based on a cumulative $100 \mathrm{mSv}$ dose averaged over five years, suddenly shifting the parameters for 'low-level' radiation and designating the general public with the level previously designated to nuclear workers.

The US Government advised a mandatory evacuation zone of 50 miles (80 kilometres). Several nations' embassies in Tokyo evacuated their staff. Of roughly 2 million in Fukushima Prefecture, about 80,000 people from 11 municipalities were ordered to evacuate while another 80,000 evacuated voluntarily. By late 2015, about 118,862 remained evacuated. ${ }^{30}$ Sixty thousand of these people live in temporary housing and many lacked basic needs. There were many evacuees who sought public housing

27 There is discrepancy on this measurement. Officially, the Japanese Government calculates 0.23 microSv/h $=1 \mathrm{mSv} / \mathrm{y}$ based on an average eight hours/day outdoors per person. The ICRP, however, calculates $0.08 \mathrm{microSv} / \mathrm{h}=1 \mathrm{mSv} / \mathrm{y}$. en.wikipedia.org/wiki/Sievert-ICRP_definition_of_the_sievert. When including normal background radiation, calculations normally vary between 0.11 and 0.18 microSv/h. This is complicated by the fact that radiation from Fukushima Daiichi has been and continues to be distributed across the entirety of Japan, so that normal background post-3.11 is in fact abnormally elevated. See See Hiroshi Ishizuka, 'Cesium from Fukushima Plant Fell all over Japan', Asahi Shimbun, 26 November 2011, ajw.asahi.com/article/0311disaster/fukushima/aj201111260001. Since the time of writing, this article has been made unavailable online. For verification, an online mirror link can be found at: www.infiniteunknown.net/2011/11/27/cesium-from-fukushima-plantfell-all-over-japan-even-on-okinawa-1700-km-from-nuke-plant/.

28 Kataoka Terumi on 18 May 2012 as recorded for the Fukushima kokusodan (Fukushima plaintiffs) presentation to the Fukushima district attorney's office against 33 TEPCO past and present officers, government officials and medical experts made in 2013. See N. Field and M. Mizenko eds, Fukushima Radiation: Will You Still Say No Crime Was Committed?, Amazon Digital Services: Complainants for Criminal Prosecution of the Fukushima Nuclear Disaster, 1st edition (12 May 2015), 360.

29 The Radiation Safety Level law permits nuclear workers $100 \mathrm{mSv}$ over 5 years and no more than $50 \mathrm{mSv}$ in any year; female workers no more than $5 \mathrm{mSv}$ in 3 months; denies citizens entry to areas of $5.2 \mathrm{mSv} / \mathrm{y}$, women are limited to $2 \mathrm{mSv} / \mathrm{y} ; 5 \mathrm{mSv}$ is the threshold for claims of occupational disease; food in general is measured below $1 \mathrm{mSv} / \mathrm{y} ; 5 \mathrm{mSv}$ and above prohibits residence and consumption of food and water.

30 Although it was reported by the end of 2015 that this number had dropped to below 100,000, there was some discrepancy in calculation as those who had bought houses in the locations they had evacuated to were no longer included as 'evacuees'. See Editors, 'Fukushima Nuclear Evacuees Fall Below 100,000', Japan Times, 9 January 2016, www.japantimes.co.jp/news/2016/01/09/national/ fukushima-nuclear-evacuees-fall-100000/\#.VpDnE1LzN_1. 
who have been turned away. ${ }^{31}$ There are additional evacuees affected by the earthquakes and tsunami who come from other prefectures (including parts of Miyagi and Ibaraki), some of whom were also affected by radiation exposure.

The situation in many villages within contaminated areas signifies how government policies have further exposed a wide range of people-farmers, shopkeepers, taxi drivers, factory workers, mothers (as reproductive workers), school students, local public servants-to conditions informal workers have long had to endure. In several cases (i.e. Iitate, Minami Soma, Namie), the notification of residents of radiation danger was delayed and potassium iodide pills were not distributed. Similarly, data on weather patterns and distribution gathered by the SPEEDI monitoring system ${ }^{32}$ was suppressed. These populations were not adequately informed of what the dose readings meant in terms of health risk. When people did seek measurement and treatment for their likely exposures, hospitals and other institutions with the requisite measuring technologies refused to measure them, as it was deemed 'there was no reason for internal contamination and so there was no reason to measure. ${ }^{33}$ These people unwittingly became hibakusha (被曝者), broadly defined as victims of radiation exposure.

Even though the Fukushima Daiichi nuclear disaster has caused nearpermanent pollution, the conflation of the radiation problem with tsunami and earthquake destruction to be managed as a single largescale 'clean-up', reconstruction and revitalisation operation as instituted by the National Resilience Council 2013 has occluded the materiality of radiation. Informal workers on 'decontamination projects' washed down public buildings and homes and scraped up and replaced soil and sludge contaminated at levels found for example at between 84,000-446,000

31 By the end of 2015, Fukushima Prefecture had built housing for around 17 per cent of the 43,700 Fukushima households that remained without a permanent home. This was based on the categorisation of 'long-term evacuee' as only pertaining to those who only wanted to remain evacuated until evacuation orders had been lifted. Those who wanted to remain evacuated permanently or until safety had been proven were not considered 'long-term evacuees'. Editors, 'Nuclear evacuees surveyed about living in public housing later became non-eligible', The Mainichi, 5 December 2015, mainichi.jp/english/articles $/ 20151205 / \mathrm{p} 2 \mathrm{a} / 00 \mathrm{~m} / 0 \mathrm{na} / 013000 \mathrm{c}$. Since the time of writing, this article has been made unavailable online. For verification, an online mirror link can be found at: dunrenard. wordpress.com/2016/page/153/.

32 SPEEDI monitoring system is the computer-based emergency response system linked to the Japan Weather Association and Science and Technology Agency of Japan to predict radiological impacts in local and workplace areas due to nuclear accident.

33 Takahashi Kei in Allain de Halleux, Fukushima e yōkosō, vol. 1 (at 4 min 40 sec), 14 June 2013, www.youtube.com/watch?v=bjv1b6Zn9DY. Accessed 15 May 2015. 
Becquerels per kilogram $(\mathrm{Bq} / \mathrm{kg})$ in Kōriyama $(60 \mathrm{~km}$ from Fukushima Daiichi)..$^{34}$ They also collected waste that included radioactive debris, uniforms and tools. The organic waste is stored on government-purchased land in black industrial bags piled in large walls and mounds to create a sort of buffer zone on town margins and in areas determined as longterm irradiated zones. ${ }^{35}$ Other contaminated waste is burned in newly constructed incinerators in towns nearest the plant (such as Futaba, Okuma, Naraha, Tamura, Tomioka, with more planned) in addition to the incineration already underway in major cities since 3.11 , even while evacuees are being compelled to return to some of them (Tamura, Kawauchi, Naraha) where evacuation orders have been lifted. In addition, in June 2016 the Ministry of the Environment approved radioactive soil of up to $8,000 \mathrm{~Bq} / \mathrm{kg}$ to be reused in national public works. Although stipulated to be used for roads and barriers (such as sea walls) under a layer of non-contaminated materials, there is concern that these will corrode over time leading to recirculation in the environment.

As compensation schemes are contingent upon where evacuees come from (whether these are areas where there are plans to lift evacuation orders, areas pending decontamination in the shorter term, or those deemed difficult to return to), those mandatory evacuees without property have received on average 100,000 yen per month while voluntary evacuees have received 60,000 yen per month, even if radiation levels in their residential areas were high. The return to towns that received over $50 \mathrm{mSv} / \mathrm{y}$ (Futaba, Namie, Okuma) remains unlikely for decades, but if evacuees do return to other villages, they risk lifetime re-exposures of up to $20 \mathrm{mSv} / \mathrm{y}$. In late 2015, Iitate village, for example, was divided into Areas 1 and 2, which

34 Wada Nanako (Hanawa-machi liaison for the incineration of radioactive debris and member of Fukushima kokuso-dan) in Anonymous, Témoignages No.1, Association Franco-Japonaise ASUKA 2014: 13 (1-18). For a copy, contact www.asuka-association.org/contact/. The calculation of radiation distributed in soil as it translates to potential damage to the human body has significant variables and is contested. The provisional safety limit was $500 \mathrm{~Bq} / \mathrm{kg}$, which was lowered to 100 $\mathrm{Bq} / \mathrm{kg}$ in Japan after Fukushima. The ICRP calculated that a total body activity of 1,400 Becquerels would correspond to $20 \mathrm{~Bq} / \mathrm{kg}$ of body weight in a $70 \mathrm{~kg}$ adult and is equivalent to $0.1 \mathrm{mSv} / \mathrm{y}$ exposure. That would make the internationally accepted limit of $1 \mathrm{mSv} / \mathrm{y}$ equate to $200 \mathrm{~Bq} / \mathrm{kg}$ in a $70 \mathrm{~kg}$ adult or 14,000 Bq in soil. See Stephen Starr, 'Implications of the Massive Contamination of Japan with Radioactive Cesium', 11 March 2013, Helen Caldicott Foundation Symposium, New York Academy of Medicine. For an alternative calculation see fn 61.

35 Watanabe Miyoko (Tamura) observed that in spite of their protests, " 400 tons per day of irradiated waste is burned everywhere. [This is planned] in our village factory'. 'Témoignages No.1', 2014. Further, Wada Nanako testified that 'Incinerators have been built, sometimes secretly, in Samegawa, Sōma, Fukushima, Kōriyama [and Miyakoji in Tamura]. There will be 20 built in total'. 'Témiognages No. 1', 2014: 13. 
are being prepared for repopulation (54,000 people), and Area 3, which so far remains out of bounds. Although the topsoil contaminated with Caesium was stripped and replaced (i.e. returning $0.6 \mathrm{microSv} / \mathrm{h}$ ) and its houses and roads were washed down, 96 per cent of litate remained at $1 \mathrm{microSv} / \mathrm{h}$. As Iitate is 75 per cent forest, which trapped a large stock of contamination, the land re-concentrates through radiation circulation (hence, quickly returned to $2.6 \mathrm{microSv} / \mathrm{h}$ ). ${ }^{36}$ If the majority in Iitate, who are primarily agricultural workers, can no longer harvest vegetables, rice, wild mushrooms and vegetables (sansai 山菜) or burn wood for heat, and their houses are re-irradiated, then only the semi-autonomous elderly are likely to return. By August 2015, less than 10 per cent of roughly 14,000 eligible had applied for temporary return. ${ }^{37}$

So-called 'decontamination' and 'remediation' has been deployed to justify redefining evacuation boundaries and lifting evacuation orders so as to cut compensation payments. Following the 37th National Emergency Response Headquarters meeting held at the Prime Minister's Office in June 2015 in which the Prime Minister decreed that 'evacuees must return to their hometowns as quickly as possible and start new lives', ${ }^{38}$ in late August 2015 evacuees were told if they chose to return home they would receive a one-off payment of 100,000 yen per household. If they did not, once evacuation orders had been lifted, 'free rent' (yachin hojo 家賃補助) for voluntary evacuees would be cut by March 2017 at the very latest. ${ }^{39}$ Further, the government announced its intention to partially lift the restriction on the 'difficult-to-return zone' by 2022 so as to counteract the negative image of the area and its produce. ${ }^{40}$ Without alternative income, and with a significant housing shortage due to the restriction

36 Greenpeace, 'Investigation Exposes Failure of Fukushima Decontamination Program', 21 July 2015, www.greenpeace.org/japan/ja/news/press/2015/pr20150721/20150721-Press-Release-Greenpeace -investigation-exposes-failure-of-Fukushima-decontamination-program-/. Accessed 22 July 2015.

37 In other towns such as Naraha, where an estimated 46 per cent of 7,368 registered evacuees hope to return while only 780 are willing to return immediately, personal radiation monitors were distributed and radiation monitoring of tap water and water filtration systems implemented to reassure them that it was safe. See 'Evacuation Order Lifted Completely in Naraha near Wrecked Fukushima Plant', Japan Times, 5 September 2015, www.japantimes.co.jp/news/2015/09/05/national/ japan-to-lift-evacuation-order-for-fukushima-town-of-naraha/.

38 Government of Japan (GoJ), The Prime Minister of Japan and his Cabinet, June 2015, japan. kantei.go.jp/97_abe/actions/201506/12article1.html.

39 Editors, 'Fukushima Prefecture Looking to End Free Rent for Voluntary Disaster Evacuees in 2017’, The Mainichi, 16 June 2015, mainichi.jp/english/articles/20150616/p2a/00m/0na/015000c. Accessed August 2015.

40 Otsuki Noriyoshi, 'Ban to be Lifted on Fukushima's Worst Affected Zone by 2022', Asahi Shimbun, 1 September 2016, www.asahi.com/ajw/articles/AJ201609010066.html. 
of new public housing, many have been and will be forced to return to contaminated areas, to endure radiation exposure without compensation. If only the elderly return, there will be few prospects for young families in such towns where there is little local business and infrastructure, and public facilities and housing are in disrepair.

In Naraha, between May and August 2015, ambient readings in populated areas officially determined as 'low or moderate' returned $0.3-0.7 \mathrm{microSv} / \mathrm{h}$ and soil samples returned 26,480-52,500 Bq/kg of Caesium 137 and 134 combined (and 18,700 Bq/kg in the town's water reservoir)..$^{41}$ While the majority of former residents are more likely to either pull down their houses and sell the land or maintain their homes as vacationers, there is additional private and state pressure to industrialise these former idylls as 'reconstruction hubs'. As part of the 'Innovation Coast' plan, for example, 1,000 irregular workers have resided on the town's outskirts as they built a giant research facility (estimated cost: 85 billion yen) to train hundreds of workers in reactor simulations and use of specialised robots. As industry colonises and transforms such towns, the pressing concern of unmitigated radiation levels in soil, forests and water, whether from distribution or recirculation, remains due to the long-lived decay and harmful effects of these radionuclides.

Similarly, in the effort to stimulate business, highways (Route 6) and train lines (Jōban line) passing directly through the (former) evacuation zone were reopened in 2015, although traffic must still travel with closed windows at the time of writing. Regular users of these corridors such as railway and transport workers and irregular nuclear workers accumulate higher doses from regular exposure while radioactive particles attached to vehicles are dispersed beyond contaminated areas. Clearly, a containment and permanent resettlement approach has been deemed untenable in the belief it would disrupt economic productivity levels. As one high school student insightfully observed, 'Sensei ... If they [really wanted to turn] Fukushima into an evacuation zone they'd have to block the Route 4 highway, Tōhoku expressway and Shinkansen'. ${ }^{42}$ Nevertheless, in lieu of overall reconstruction costs less conservatively estimated at half a trillion dollars, it may have been cheaper in the longer term to adopt permanent resettlement, education, health treatment and work creation strategies.

41 Iwaki Monitoring Centre, www.iwakisokuteishitu.com/pdf/weekly_data.pdf.

42 Kazuki Jinno (35 years old) in Fukushima Radiation, 2015: 537. 


\section{Official Medicine: The (II)logic of Radiation Dosimetry}

On what basis have these policies on radiation from Fukushima Daiichi been made? Instead of containing contamination, the authorities have mounted a concerted campaign to convince the public that it is safe to live with radiation in areas that should be considered uninhabitable and unusable according to internationally accepted standards. To do so, they have concealed from public knowledge the material conditions of radiation contamination so as to facilitate the return of the evacuee population to 'normalcy', or life as it was before 3.11. This position has been further supported by the International Atomic Energy Agency (IAEA), which stated annual doses of up to $20 \mathrm{mSv} / \mathrm{y}$ are safe for the total population including women and children. ${ }^{43}$ The World Health Organisation (WHO) and United Nations Scientific Commission on the Effects of Atomic Radiation (UNSCEAR) also asserted that there were no 'immediate' radiation related illnesses or deaths (genpatsu kanren shi 原発 関連死) and declared the major health impact to be psychological.

While the central and prefectural governments have repeatedly reassured the public since the beginning of the disaster that there is no immediate health risk, in May 2011 access to official statistics for cancer-related illnesses (including leukaemia) in Fukushima and southern Miyagi prefectures was shut down. On 6 December 2013, the Special Secrets Protection Law (Tokutei Himitsu Hogo Hō 特定秘密保護法) aimed at restricting government employees and experts from giving journalists access to information deemed sensitive to national security was passed (effective December 2014). Passed at the same time was the Cancer Registration Law (Gan Tōroku Hō 癌登録法), which made it illegal to share medical data or information on radiation-related issues including evaluation of medical data obtained through screenings, and denied public access to certain medical records, with violations punishable with a 2 million yen fine or 5-10 years' imprisonment. In January 2014, the IAEA, UNSCEAR and Fukushima Prefecture and Fukushima Medical University (FMU) signed a confidentiality agreement to control medical data on radiation. All medical personnel (hospitals) must submit data

43 IAEA, 'Actions to protect the public in an emergency due to severe conditions at Light Water Reactor', May (2013): 97, accessed August 2015, www-pub.iaea.org/MTCD/publications/PDF/ EPR-NPP_PPA_web.pdf. 
(mortality, morbidity, general illnesses from radiation exposures) to a central repository run by the FMU and IAEA ${ }^{44}$ It is likely this data has been collected in the large Fukushima Centre for Environmental Creation, which opened in Minami-Sōma in late 2015 to communicate 'accurate information on radiation to the public and dispel anxiety'.

This official position contrasts with the results of the first round of the Fukushima Health Management Survey (October 2011 - April 2015) of 370,000 young people (under 18 at the time of the disaster) in Fukushima prefecture since 3.11, as mandated in the Children and Disaster Victims Support Act (June 2012). ${ }^{45}$ The survey report admitted that paediatric thyroid cancers were 'several tens of times larger' (suitei sareru yūbyōsū ni kurabete sūjūbai no ōda de öi 推定される有病数に比べて数十倍の オーダーで多い) than the amount estimated. ${ }^{46}$ By 30 September 2015, as part of the second-round screening (April 2014-March 2016) to be conducted once every two years until the age of 20 and once every five years after 20 , there were 15 additional confirmed thyroid cancers coming to a total of 152 malignant or suspected paediatric thyroid cancer cases with 115 surgically confirmed and 37 awaiting surgical confirmation. Almost all have been papillary thyroid cancer with only three as poorly differentiated thyroid cancer (these are no less dangerous). By June 2016, this had increased to 173 confirmed (131) or suspected (42) paediatric thyroid cancer cases. ${ }^{47}$

The National Cancer Research Center also estimated an increase of childhood thyroid cancer by 61 times, from the 2010 national average of 1-3 per million to 1 in 3,000 children. Other estimates of exposure to radiation, obtained from direct thyroid measurements in Namie town in April 2011, although discontinued under government pressure, also returned much higher results than official estimates (i.e. 80 per cent

44 Editors, 'Gan tōroku hō no seiritsu, kuni ga zenkoku no kanja jōhōhan wo database ni', Huffington Post, 6 December 2013, www.huffingtonpost.jp/2013/12/06/cancer-datebace-japan_n_4396656.html. Accessed 15 July 2015.

45 The Act stipulates expanded health checkups; assessment of doses and their health effects; alleviation of health concerns; long-term support for radiation effects; support for choice of residence and settlement; provision of regular medical care; reduction of medical expenses for children (unborn included) and pregnant women; lifelong medical checkups for those from contaminated areas.

46 Fukushima Prefectural Government, 19th Prefectural Oversight Committee Meeting for the Fukushima Health Management Survey, Fukushima Prefecture, 18 May (2015): 1, www.pref. fukushima.lg.jp/uploaded/attachment/115335.pdf.

47 Yuri Oiwa, '15 More Child Thyroid Cancer Cases Found in Fukushima', Asahi Shimbun, 7 June 2016, www.asahi.com/ajw/articles/AJ201606070042.html. 
positive, 1 at $89 \mathrm{mSv}, 5$ over $50 \mathrm{mSv}, 10$ at $10 \mathrm{mSv}$ or under). ${ }^{48}$ In April 2014, Dr Tsuda Toshihide, an epidemiologist at Okayama University, declared this a 'thyroid cancer epidemic' (kojōsen densenbyo 甲状腺伝染 病), and predicted multiple illnesses from long-term internal radiation below $100 \mathrm{mSv} / \mathrm{y}$ and advocated for a program of outbreak (emergency or rapid) epidemiology in and outside Fukushima. ${ }^{49}$ Similarly, a Tokyobased physician, Dr Mita Shigeru, circulated a public statement notifying his colleagues of his intention to relocate his practice to Okayama due to overwhelming evidence of unusual symptoms in his patients (roughly 2,000). Given that soil in Tokyo post-Fukushima returned between 1,000 and $4,000 \mathrm{~Bq} / \mathrm{kg}$, as compared to an average of $500 \mathrm{~Bq} / \mathrm{kg}$ (Cs 137 only) in Kiev soil, Mita pointed to a correlation between these symptoms and the significant radiation contamination in Tōhoku and metropolitan Tokyo. $^{50}$

While results from the Fukushima Health Survey demonstrate flaws in the official dosimetry model and public safety campaign, the survey itself also has clear limitations. It is limited to subjects in a specific age bracket in one prefecture and one non-fatal illness (thyroid cancer, which can be treated with surgery but has lifelong side effects) from the ingestion of one radionuclide (Iodine 131) with a relatively short half-life (eight days) that comprised only 9.1 per cent of the total releases. Its dosimetry is based on the National Institute of Radiological Sciences (NIRS) model, ${ }^{51}$ which is for external exposure only, does not account for exposures in the initial days of the disaster and uses Japanese Government data that has been criticised for underestimating releases and exposures. ${ }^{52}$ Further, the survey ignores the damage from the bulk of the total inventory including longer-

48 The most contaminated area is Nakadōri (605 per million, 50 times higher than total) while other parts are 12 times the total. Editors, 'Fukushima Government Terminated Iodine 131 Exposure Study, Citing it Might Concern Residents', Simply Info, 14 June 2013, www.fukuleaks.org/ web/?p=6243. Accessed January 2015.

49 Ministry of the Environment (MoE), 8th Expert Meeting, Status of Disaster Victims' Health Management, 16 July 2014, in Editors, 'Running Backwards on Health Support after the Nuclear Accident: Ministry of Environment Expert Meeting', Tokyo Shimbun, 22 July 2014.

50 Mita Shigeru, 'Why did I Leave Tokyo' [letter to Association of Doctors in Kodaira, WNCR, 16 July 2014, www.save-children-from-radiation.org/2014/07/16/a-tokyo-doctor-who-has-movedto-western-japan-urges-fellow-doctors-to-promote-radiation-protection-a-message-from-dr-mita-tohis-colleagues-in-kodaira-city-t/. Accessed 17 July 2014.

51 Keiichi Akahane et al., 'NIRS External Dose Estimation System for Fukushima Residents after the Fukushima Dai-ichi NPP Accident', Nature Scientific Reports 2013 (3): 1670, www.ncbi.nlm.nih. gov/pmc/articles/PMC3628369/.

52 See 'New Radiation Release Estimates Compiled', Simply Info, 4 November 2013, accessed January 2015, www.fukuleaks.org/web/?p=11668. 
lived radionuclides (such as Plutonium 239, Caesium 137, Strontium 90, Americium 241, among others), some of which are more difficult to measure on ordinary and less sensitive Geiger counters and which have been distributed and continue to circulate across a wide area. It also ignores other organ diseases, unusual chronic illnesses and premature births and stillbirths, voluntary terminations and birth deformities occurring in and beyond Fukushima prefecture.

In addition to the control of relevant data, the government has used other methods to encourage residents to stay in radiation-contaminated areas. In May 2011, Dr Yamashita Shunichi, then co-director of Fukushima Medical University and the Fukushima Health Management Survey and a specialist from Nagasaki on radiation illness in Chernobyl, declared there was a 1 in 1 million chance of children getting any kind of cancer from radiation and there would be negligible health damage from radiation below $100 \mathrm{microSv} / \mathrm{h}$, and prescribed smiling as an aid to living with radiation to a public audience in Fukushima. ${ }^{53}$

Dr Yamashita is only one among a host of politicians, bureaucrats, experts and advertising and media consultants who support the post-3.11 safety mantra of anshin (secure 安心), anzen (safe 安全), fukkō (recovery 復 興). Through public meetings, media channels, education manuals and workshops,${ }^{54}$ local citizens in Fukushima Prefecture were inundated with optimistic and reassuring messages, also known as 'risk communication discourse', and central and prefectural government-sponsored 'health seminars' encouraging a 'practical radiation protection culture' in which they have been urged to take responsibility (jiko sekinin 自己責任) for their own health (e.g. wearing glass badges, self-monitoring, avoiding hotspots), form bonds of solidarity (kizuna 絆) with their community and participate in the great reconstruction (fukkatsu 復活) for the revitalisation of a resilient nation (kyojinka kokka 強勒化国家) as a whole. To counteract baseless rumours (ryügen higo 流言蜚語) and the negative impact of gossip (fühyō higai 風評被害) of radiation in contaminated

53 See 'Unbelievable Comment by Mr. Yamashita', 8 May 2011, accessed 15 August 2015, www. youtube.com/watch?v=UOgaBUDFeb4\&feature=related. Another physician, Dr Arai from Asahi Nairyō Clinic, Kōriyama, who subscribes to the hormesis theory, augmented the description of 'low level radiation' (up to $50 \mathrm{mSv} / \mathrm{y}$ ) as 'an angel's smile', while claiming that food with small amounts of radiation would attract a premium, and that Fukushima would become the number one health land in the country. See Asahi Nairyō Clinic, December 2012, e.oisyasan.ne.jp/asahi-cl/topics/radi.html. 54 Such as 'Public Opinion Policy Related to Nuclear Power' by JAERO (Japan Atomic Energy Research Organisation/Nihon Genshiryoku Bunka Zaidan); 'The Nuclear Power Story' by the Ministry of Education (MEXT); 'Nuclear Fuel Cycle lectures' by the Ministry of Finance (MoF). 
Fukushima produce, citizens in and beyond Fukushima Prefecture, and even non-citizens, have been encouraged to buy and consume Fukushima produce as an expression of moral and economic support (through slogans such as 'Ganbare Fukushima!' がんばれ福島!). At the same time, to reduce 'radiophobia' and anxiety, while focusing on the psychological impact from stress, health risks from radiation exposures have been trivialised and/or normalised for the general public. ${ }^{55}$

This approach is backed up by international nuclear-related agencies. As stipulated on 28 May 1959 in the 'WHA12-40' agreement, the WHO is mandated to report all data on health effects from radiation exposures to the IAEA, which controls publication. On no other medical health issue is the WHO required to defer publication responsibilities to another institution. Scientific expertise at the IAEA primarily lies in nuclear physics (radiology and dosimetry) as opposed to epidemiology and medical expertise on radiation effects to living tissue. The IAEA and its related UN bodies are informed by the International Commission of Radiation Protection (ICRP) recommendations on radiation dose assessments derived from the Atomic Bomb Casualty Commission/ Radiation Exposure Research Foundation (ABCC/RERF) lifetime studies of hibakusha (被爆者) in Hiroshima and Nagasaki. This dosimetry is primarily based on an average exposure of a 20-30-year-old 'reference man' (originally modelled on a US Army soldier) mainly to short-term one-off acute gamma radiation exposure. While it recommends caution, the ICRP continues to maintain that anything below $100 \mathrm{mSv} / \mathrm{y}$ is a 'low dose' and that the risk of 'stochastic effects' are yet to be scientifically proven beyond doubt. Within this framework, it would seem reasonable to raise the level from 1 to $20 \mathrm{mSv} / \mathrm{y}$.

The ABCC/RERF studies ignored, however, biological contingencies of sex, age, constitution, other health conditions and the variegated effects (including complicating chemical and metabolic dynamics)

55 MEXT booklets designed for students at all levels assert that (a one-time external exposure dose) below $100 \mathrm{mSv} / \mathrm{y}$ is negligible; natural and man-made radiation have the same effect; cancer has multiple causes and is difficult to trace; and that radioactive materials are no longer harmful after they bond with soil. See www.mext.go.jp/b_menu/shuppan/sonota/attach/1313004.htm. Further, Kataoka Terumi testified that public health leaflets in Kōriyama were distributed stating, 'In the future, one in two children in your class will have a cancer, and ten of them will die', as part of a program to familiarise children to the realities of cancer. Kataoka reports that the leaflets were subsequently withdrawn from circulation due to a negative public response.' Association FrancoJaponaise (ASUKA), Témoignages No.1 [Statements by Fukushima genpatsu kokuso-dan] (2014): 7. For a copy contact: www.asuka-association.org/contact/. 
from both internal and external exposures to different radionuclides of all types ('low level' internal radiation is at least 20 times greater). After Chernobyl, the WHO and IAEA used the ICRP dose model to conclude that there were up to 56 deaths of 'liquidators' (clean-up workers) from acute radiation sickness and 4,000 additional cancers; ${ }^{56}$ and that environmental effects such as lifestyle (i.e. parental alcoholism, smoking) and 'radiophobia' (stress and depression) contributed to excess illnesses in 80 per cent of adult cases. It also concluded that no harm would be received by the 2 million farmers and more than 500,000 children who continued living in radioactive areas in Belarus.

Nevertheless, it is no longer possible to ignore a significant body of research, including 20 years of scientific studies compiled in Belarus and Ukraine that show serious depopulation, ongoing illnesses and state decline. ${ }^{57}$ These studies have found genetic effects within a radius of $250-300 \mathrm{~km}$ from Chernobyl, while children's health in Belarus has declined from a situation where 80 per cent of the child population was healthy prior to the Chernobyl disaster to a situation post-Chernobyl where only 20 per cent are healthy. ${ }^{58}$ In 1995, Professor Nechaev from the Ministry of Health and Medical Industry (Moscow) stated that 2.5 million people were irradiated from Chernobyl in the Russian Federation, the Ukrainian Prime Minister Marchuk stated that 3.1 million had been exposed to Chernobyl radiation and Professor Okeanov from Belarus observed a spike in leukaemia and cancers among liquidators in Gomel relative to duration of exposure. ${ }^{59}$ By 2001, of 800,000 healthy Russian and Ukrainian liquidators (with an average age of 33 years) sent to decontaminate, isolate and stabilise the

56 The Chernobyl Forum, 'Health effects of the Chernobyl accident and special health care programmes', Vienna, April (2006): 113, accessed July 2015, www.who.int/ionizing_radiation/ chernobyl/WHO\%20Report $\% 20$ on\%20Chernobyl\%20Health\%20Effects\%20July\%2006.pdf.

57 See Alexey Yablokov, Vassili Nesterenko, Alexey Nesterenko, Chernobyl: Consequences of the Catastrophe for People and the Environment (New York: Annals of the New York Academy of Sciences, 2009). This was recognised by President of the Academy of Sciences in Belarus in December 1999, and confirmed in April 2000 by Vice-Minister of Health of Belarus at a parliamentary hearing about the Chernobyl disaster. See also Wladimir Tchertkoff, 'The Crime of Chernobyl - a Model for Fukushima', Independent WHO [April 2013], 5 February 2014, independentwho.org/en/2014/02/05/ chernobyl-model-fukushima/. Accessed 10 July 2015.

58 Statement from the President of the Academy of Sciences in Belarus, in December 1999, confirmed by the Vice-Minister of Health of Belarus at a parliamentary hearing about the consequences of the Chernobyl disaster, in April 2000. See Tchertkoff, 'The Crime of Chernobyl', 2014.

59 Nechaev and Okeanov presented at the 1995 WHO-Geneva Conference, the Proceedings of which have remained inaccessible to the public. See Michel Fernex, 'The Chernobyl Catastrophe and Health', 3 May (2000): 5, accessed 1 July 2015, independentwho.org/media/documents_autres/ michel_fernex_the_chernobyl_catastrophe_and_health_03may2000_en.pdf. 
reactor, 10 per cent had died and 30 per cent were disabled. By 2009, 120,000 liquidators had died, and an epidemic of chronic illness and genetic and perigenetic damage in nuclear workers' descendants appeared (this is predicted to increase over subsequent generations). ${ }^{60}$ The full extent of the damage will not be understood until the fifth generation of descendants. By the mid-2000s, 985,000 additional deaths between 1986 and 2004 across Europe were estimated as a direct result from radiation exposure from Chernobyl. ${ }^{61}$

Given this background of regulatory capture and radical discrepancies in methods and estimates prior to the Fukushima disaster, it is less surprising that there may be a process of regulatory capture and cover up underway in response to Fukushima Daiichi. In December 2011, a Cabinet Office Working Group chaired by RERF chairman Nagataki Shigenobu consisted of 18 Japanese ICRP members (including Niwa Otsura and Yamashita Shunichi). The experts invited Mr Jacques Lochard to provide external expertise. Lochard is an economist, ICRP member, Director of the Center of Studies on the Evaluation of Protection in the Nuclear Field (CEPN) (funded by Electricité de France EDF), and co-director of the CORE-ETHOS Programme in Chernobyl (1996-1998).

The CORE (Cooperation and Rehabilitation in the Belarusian territories contaminated by Chernobyl) Programme organised a takeover of radioprotection health centres in Ukraine and Belarus, and delayed a health audit beyond five years while it produced the ETHOS report outlining a 'sustainable system of post-radiological accident management for France and the European Union'. ${ }^{62}$ While local scientists (led by Yuri Bandazhevsky and Vassili Nesterenko) recommended whole body counts (WBC) for each child (in which 50,000 children would be tested with

60 R. I. Goncharova and N. I. Ryabokon, 'Dynamics of Gamma-emitter Content Level in Many Generations of Wild Rodents in Contaminated Areas of Belarus', Radiobiological Consequences of Nuclear Accidents 2nd International Conference, 25-26 October 1994.

61 Yablokov et al., Chernobyl, 210.

62 ETHOS and CORE are products of the French nuclear industry, financed through Centre d'étude sur l'Evaluation de la Protection dans le domaine Nucléaire (CEPN), formed in 1976 by EDF, the Autorité de Sureté Nucléaire (ASN) and/or the Commissariat à l'Énergie Atomique et aux Énergies Alternatives (CEA). The ETHOS co-directors (M. Henry Ollagnon, l'Institut National d'Agronomie Paris-Grignon; Gilles Hériard-Dubreuil, Mutadis Consultants; Jacques Lochard, CEPN) initiated the European CORE program, with the support of the Chernobyl Committee of the Government of Belarus, the United Nations Development Programme, French and German embassies, the European Commission, the Swiss Agency for Development and Cooperation of Switzerland, United Nations Educational, Scientific and Cultural Organization (UNESCO), the World Bank and four districts of Belarus. 
spectrometers), food measurement, dietary radioprotection (prophylaxis through adsorbents) and resettlement of those exposed to radiation over $1 \mathrm{mSv} / \mathrm{y},{ }^{63}$ the ETHOS manual concluded that in a similar radiological event in western Europe, resettlement would be restricted to those exposed to more than $100 \mathrm{mSv} / \mathrm{y}$. By factoring in 'social, economic and political' costs, ETHOS proposed ways for populations to live with radiation, and identified psychosomatic illnesses derived from 'stress' based on unfounded fears (i.e. 'radiophobia') of radiation as the greatest health risk. After a prolonged delay, in 1996 the IAEA and WHO finally settled on $5 \mathrm{mSv} / \mathrm{y}$ as the mandatory evacuation limit in a compromise between the Soviet $(1 \mathrm{mSv} / \mathrm{y})$ and western European $(100 \mathrm{mSv} / \mathrm{y})$ recommendations after Chernobyl. ${ }^{64}$ These agencies targeted 'alarmist' reports (including social protests) as encouraging 'radiophobia', stressing the psychological impacts of radiological events.

In post-3.11 Japan, the Japanese Cabinet Office Working Group ${ }^{65}$ reinforced the IAEA dosimetry regime by reiterating that cancers only emerge four to five years after exposure, that increases in cancers within

63 Professor Vassili Nesterenko (Institute of Nuclear Energy of the Academy of Sciences of Belarus) was removed from his post after demanding a $100 \mathrm{~km}$ mandatory evacuation zone in July 1987. He formed the Institute of Radiation Safety (Belrad) and organised 370 radiological monitoring centres in contaminated villages in Belarus to train doctors, teachers, nurses, parents and children in radioprotection ecanthropogammetric measures, pectin diets and information. Dr Yuri Bandazhevsky (Gomel Medical Institute) identified the etiology of low-level radiation impacts on organs and tissues. In 1994, Nesterenko and Bandazhevsky worked in the contaminated territories. Bandazhevsky found above $50 \mathrm{~Bq} / \mathrm{kg}$ would lead to irreversible lesions to vital organs. From 1996, Belrad Institute measured internal contamination with spectrometers in the villages and Nesterenko used apple pectin as an absorbent of Cs137. This reduced Cs137 in the child's body by 60-70 per cent. See Tchertkoff, 'The Crime of Chernobyl', 2014.

64 IAEA Conference, 'One Decade after Chernobyl: Summing up the Consequences of the Accident', 8-13 April 1996, www-pub.iaea.org/mtcd/publications/pdf/te_964v1_prn.pdf.

65 Nagataki stated that 99.8 per cent of 1,080 children measured in March 2011 were under $5 \mathrm{mSv}$ and nobody exceeded $50 \mathrm{mSv}$. MoE Expert Group members include Nagataki Shigenobu—Emeritus Professor at Nagasaki University, former chairman of Radiation Effects Research Foundation, mentor of Yamashita Shunichi, chair of Cabinet Office Working Group; Niwa Otsura-Cabinet Office Working Group 2011, retired Kyoto University Professor (molecular biology and radiation biology), Special Professor at Fukushima Medical University, WHO Expert Group, editor Health Risk Assessment from the Nuclear Accident after the 2011 Great East Japan Earthquake and Tsunami, Based on a Preliminary Dose Estimation (February 2013), ICRP member, funded by Federation of Electric Power Companies of Japan (Denjirenkai), advocate of one-tenth of WHO estimates; Endo Keigo-Kyoto College of Medical Science president; Ban Nobuhiko and Honma Toshimitsu—2013 UNSCEAR Fukushima report authors; Sasaki Yasuhito-former Expert Group chairman. 
this period could not be attributable to the accident, ${ }^{66}$ and that illnesses in people exposed to radiation below $100 \mathrm{mSv} / \mathrm{y}$ could be concealed by other carcinogenic effects and other factors (rendering them statistically negligible), and thus could not be proven to be radiation related. In fact, in July 2014, Nagataki Shigenobu declared that it would be 'disastrous to conclude [from the survey findings] an increase in thyroid cancer' was due to radiation exposure. ${ }^{67}$ Consequently, privileging a government study of the thyroid glands of 1,080 children in late March 2011 (a very small sample), Nagataki claimed that almost none had exceeded $50 \mathrm{mSv}$ for internal exposure and that 99.8 per cent of the population in Fukushima Prefecture could be estimated to have received an external dose below $5 \mathrm{mSv}$. Nagataki dismissed the need for further medical screenings, regular check-ups or internal radiation tests (whole body counter, urine and blood tests) at hospitals and clinics in Fukushima Prefecture or elsewhere.

Instead, the government appears to have adopted the ETHOS model: 'improving' community life in radiation-contaminated areas through local education and support groups; encouraging proactive self-responsibility (i.e. self-monitoring with government monitors) for children and parents (including pregnant women); stamping out 'stigma' attached to 'Fukushima' residents, the area and its produce while stigmatising 'radiophobia'; and encouraging evacuees' return after and even prior to 'decontamination'. ${ }^{68}$

66 This contradicts Ban Nobuhiko's finding on leukaemia one to two years after irradiation of lab mice, www.oita-nhs.ac.jp/member/cat5_top/cat193/cat351/post_20.html; www.labome.org/expert/ japan/oita/ban/nobuhiko-ban-572788.html. Leukaemia and thyroid tumours within one or two years was found in Belarus. See International Physicians for the Prevention of Nuclear War (IPPNW), Health Effects of Chernobyl: 25 years after the Reactor Disaster, April 2011, www.chernobylcongress. org/fileadmin/user_upload/pdfs/chernob_report_2011_en_web.pdf. Accessed March 2015.

67 Hiranuma Yuri, 'Questioning the Very Status of the Ministry of the Environment Expert Meeting Regarding the Status of Disaster Victims' Health Management', Fukushima Voice version 2e, 3 August 2014, fukushimavoice-eng2.blogspot.com.au/2014/08/questioning-very-status-of-ministry-of.html; 'Genpatsu jiko go no kenkō shiji de gyakusō: Kankyō shō’ no Senmonka kaigi', Tokyo Shimbun, 22 July 2014, www.tokyo-np.co.jp/article/tokuho/list/CK2014072202000168.html.

68 See, Yuri Oiwa, 'NRA Plan to Implement Use of Personal Dosimeters No Easy Task', Asahi Shimbun, 21 November 2013, ajw.asahi.com/article/0311disaster/fukushima/AJ201311210067. Since the time of writing, this link is no longer available. For verification, an online mirror link can be found at: www.fukushima-is-still-news.com/article-personal-dosimeters-easier-said-thandone-121232568.html. 
By September 2015, an officially estimated 3,407 people (up from 3,194 the previous year) had died from 'effects related to the great east Japan earthquake' (Daishinsai kanren shi 大震災関連死). ${ }^{69}$ In March 2015, about 1,870 deaths of those who had evacuated due to the overall disaster were deemed to have been from ill-health and suicide. By March 2016, this had increased to 2,208 deaths, while 1,386 deaths were estimated to have been caused by effects related specifically to the nuclear disaster (genpatsu kanren shi).$^{70}$ Further, a statistically significant 15 per cent drop in live births in Fukushima Prefecture in December 2011, and a 20 per cent spike in infant mortality were found to have been caused mainly by internal radiation from the consumption of contaminated food. ${ }^{71}$ Nor do statistics on abortions seem to have been factored into official accounts. As the statistics are so temporally specific, anxiety (disruption, evacuation) is unlikely to have been the major factor as the spikes would be more prolonged. It has also been extrapolated from the conservative UNSCEAR 2013 estimate of a 48,000 person Sv collective dose, that another 5,000 are expected to die from future cancers in Japan (and larger numbers to become ill). ${ }^{72}$ Using the Tondel model, however, the European Commission on Radiation Risk (ECRR), in contrast to the ICRP dose model, which estimates 2,838 excess cancers within $100 \mathrm{~km}$ radius over 50 years excluding internal radiation, estimated that 103,000 excess cancers within $100 \mathrm{~km}$ would be diagnosed within 10 years and 200,000 in the next 50 years. ${ }^{73}$

69 See GoJ, Reconstruction Agency, 25 December 2015, www.reconstruction.go.jp/topics/maincat2/sub-cat2-6/20151225_kanrenshi.pdf. See also, www.reconstruction.go.jp/topics/main-cat2/ sub-cat2-1/20141226_kanrenshi.pdf; Editors, 'Death toll grows in 3/11 aftermath', Japan Times, 5 March 2015, www.japantimes.co.jp/news/2015/03/15/national/death-toll-grows-in-311-aftermath/. 70 'Genpatsu kanren shi 1368 nin ni honshi shūkei 1 nen de 136 ninzō', Tokyo Shimbun, 6 March 2016, www.tokyo-np.co.jp/article/national/list/201603/CK2016030602000127.html.

71 Alfred Körblein, 'Increased Infant Mortality and Decline in Birth Rate after Fukushima', 6 February 2014, accessed 15 June 2015, www.strahlentelex.de/Koerblein_infant\%20mortality\%20after\%20 Fukushima.pdf; Alfred Körblein, 'Decline of Live Births Nine Months after Fukushima', February (2016), www.researchgate.net/publication/292540026_Decline_of_live_births_in_Japan_nine_months _after_Fukushima; Alfred Köblein, 'Perinatal mortality after the Fukushima accident', February 2016, www.researchgate.net/publication/291818329_Perinatal_mortality_after_the_Fukushima_accident.

72 Ian Fairlie, 'Summing up the Effects of the Fukushima Nuclear Disaster', August 2015, www. ianfairlie.org/wp-content/uploads/2015/08/Summing-up-the-Effects-of-the-Fukushima-NuclearDisaster-10.pdf. Accessed August 2015.

73 Chris Busby, 'The Health Outcome of the Fukushima Catastrophe: Initial Analysis from Risk Model of the European Committee on Radiation Risk (ECRR)', 30 March 2011, Green Audit, Occasional Paper, presented at ECRR/ GSRP conference, Charite Hospital Berlin, July 2011. 
As with informal and formal nuclear workers, if these deaths were officially recognised as being tied to radiation from Fukushima Daiichi, then the family of the deceased as main income earner would be eligible for a 5 million yen 'consolation' payment (half for others). Further, it would also imply the need for stricter radiological protection standards and a greater number of permanent evacuations and official health treatment program that would effectively limit the so-called 'benefits' associated with nuclear power generation. ${ }^{74}$ In short, it is not surprising that the overwhelming emphasis in scientific studies and public reports has been placed on psychological impacts rather than disease and deaths (particularly but not limited to nuclear workers and children) and the argumentation over the significance of thyroid cancers. The same pattern occurred after Chernobyl and Three Mile Island.

\section{Local Responses to State-Corporate Suppression and Lack of Public Health Protection}

Faced with the post-3.11 reality of government (and corporate) policy that protects economic and security interests over public health and wellbeing, the majority of the 2 million inhabitants of Fukushima Prefecture are either unconscious of or have been encouraged to accept living with radioactive contamination. People dry their clothes outside, drink local tap water and consume local food, swim in outdoor pools and the ocean, consume and sell their own produce or catches. Financial pressure after 3.11 as well as the persistent danger of social marginalisation has made it more difficult to take precautionary measures (i.e. permanent relocation, dual accommodation, importing food and water) and develop and share counter-narratives to the official message. Nevertheless, some continue to conceal their anxiety beneath a mask of superficial calm.

As Fukushima city resident Shiina Chieko observed, the majority of people seem to have adopted denial as a way to excise the present danger from their consciousness. Her sister-in-law, for example, ignored her son's 'continuous nosebleeds', while her mother had decided that the community must endure by pretending that things were no different from

74 See for example, the ICRP 2005 draft recommendations, www.icrp.org/docs/2005_recs_ CONSULTATION_Draft1a.pdf. 
pre-3.11 conditions. ${ }^{75}$ Unlike the claim that risk is evenly distributed, it is likely that greater risk is borne by those who eat processed foods from family restaurants and convenience stores, as well as infants, children and young women who are disproportionately vulnerable to internal radiation exposures. Most mothers, then, have an added burden to shield their children while maintaining a positive front in their family and community.

Some, such as Yokota Asami (40 years old), a small business owner and mother from Kōriyama (60 km from FDNPS), demonstrated initiative in voluntarily evacuating her family. She decided to return (wearing goggles and a mask, she joked) in September 2011 when her son's regular and continuous nosebleeds (in 30-minute spells) subsided. The Yokotas found themselves the victims of bullying when they called attention to radiation dangers, and were labelled non-nationals (bikokumin 非国民) who had betrayed reconstruction efforts. Her son was the only one to put up his hand when he was asked along with 300 fellow junior high school students if he objected to eating locally produced school lunches. He also chose not to participate in outdoor exercise classes and to go on respite trips instead. When it came time to take the high school entrance exam, he was told by the school principal that those who took breaks could not pass. He took the exam and failed. When he asked to see his results he found that he had, in fact, enough points to pass (the cut-off was 156 while he received 198 out of 250 points). The Yokotas decided that it was better to be a 'non-national' and protect one's health. Their son moved to live in Sapporo. ${ }^{76}$

In March 2015, Asami reported that doctors undertook paediatric thyroid operations while denying any correlation (inga kankei 因果 関係) with radiation exposures. They also urged their patients to keep their thyroid cancer a secret to enhance their employment or marriage prospects, although it would be difficult to conceal the post-operation scar. ${ }^{77}$ Yokota also indicated she knew of students having sudden heart attacks and developing leukaemia and other illnesses. ${ }^{78}$

75 Shiina Chieko, interview with the author, digital audio recording, 23 March 2015.

76 Yokota Asami, interview with the author, digital audio recording, 6 February 2015.

77 See Editor, 'Fukushima Children's Thyroid Examination: How Shunichi Yamashita Would like Doctors to Deal with the Results', Fukushima Voice, 4 May 2012, fukushimavoice-eng.blogspot.com. au/2012/05/fukushima-childrens-thyroid-examination.html. Accessed 12 June 2015.

78 Yokota Asami, interview with the author, digital audio recording, 6 February 2015. 
This seems to be supported by Mr Ōkoshi, a Fukushima city resident, whose two daughters experienced stillbirths after 3.11. While Ōkoshi found that doctors have regularly advised women in the area to abort after 3.11, presumably to avoid miscarriages and defects, they do not discuss direct causes. He also observed regular illnesses experienced by many of his friends, and some sudden deaths. After a friend (62 years old) started saying strange things, he was diagnosed with brain dysfunction. He died quickly. Another friend (53 years old) was advised by a doctor to monitor a polyp in her breast. When she sought second opinions, she discovered she had accumulated an internal dose of $22 \mathrm{mSv}$ and had a rapidly developing liver cancer. She also died quickly. ${ }^{79}$ There are many more such stories that are being actively ignored by the authorities. As Shiina put it, 'we're getting leukaemia and cataracts and we die suddenly. The TEPCO registrar has been inundated with complaints' ${ }^{80}$

While radiation contamination is clearly a health and environmental issue, state-corporate methods deployed by executives to protect (transnational) financial, industry and security interests and assets also make it a political issue. ${ }^{81}$ As things do not change by themselves, rather than turning one's frustration inward in self-blame, turning to prayer or deceiving oneself into returning to pre-3.11 lifeways in contaminated areas, Shiina states that people, particularly those most affected, must develop political consciousness.

To achieve this ambitious objective is not as complicated as it might sound. Nishiyama Chikako (60 years old), for example, returned to Kawauchi village to run for the local assembly after the mandatory order was lifted in December 2011. She found, as she commented in her blog, a link between TEPCO and the tripling of the Kawauchi budget post-3.11. Subsequently, she reported that her blog was shut down by unknown hackers on several occasions. ${ }^{82}$

This sort of information and communication control appears to be widespread. After 3.11, the central government hired advertising companies Dentsū and Hakuhōdō (formerly McCann Ericson Hakuhodo) to run a 'public acceptance' campaign. Young teams were dispatched nationwide to conduct 'public opinion guidance' (yoron yüdō 世論誘導).

$79 \mathrm{Mr}$ Ōkoshi, interview with the author, digital audio recording, 24 March 2015.

80 Shiina Chieko, interview with the author, digital audio recording, 23 March 2015.

81 Shiina Chieko, interview with the author, 23 March 2015.

82 Nishiyama Chikako, interview with the author, digital audio recording, 24 March 2015. 
The teams consisted of casual labour (earning 2,000-4,000 yen per hour) hired under a confidentiality clause (shubi gimu 守秘義務) to manipulate information (jōhō kōsaku 情報工作) and harass internet users. ${ }^{83}$

Media professionals have been subjected to similar tactics. The Asahi TV journalist Iwaji Masaki (Hōdō Station), one of the few mainstream journalists covering the Fukushima Daiichi nuclear accident in depth, for example, was intimidated by police for interviewing (December 2012) informal nuclear workers who showed shoddy decontamination practices that entailed contaminated waste disposal rather than removal and the mother of a child with thyroid cancer. Airing the program was delayed until August 2013. Before he could complete his planned segments on the US $\$ 1$ billion class action for compensation for unusual and serious illnesses filed against TEPCO, General Electric, Hitachi and Tōshiba in 2015 by sailors from the USS Ronald Reagan (which provided assistance quickly after the disaster, and among whose crew 250 were ill and three had died), ${ }^{84}$ on 29 September 2013, Iwaji was reportedly found dead in his apartment (having suffered carbon monoxide poisoning in a sealed room as he slept). Much speculation followed on social media, including both plausible reasons for suicide and testimonies from friends that knew him well that Iwaji himself stated he would never commit suicide, but the story was conspicuously ignored by major news channels. ${ }^{85}$

The former mayor of Futaba village Idogawa Katsuichi was harassed on social media for calling attention to illnesses and for the resettlement of pregnant women and children. When Kariya Tetsu characterised Idogawa in his popular manga series (Oishinbo 美味しんぼ), and depicted the manga's main character as suffering from nosebleeds after visiting Fukushima, Kariya's editors shut the series down following accusations of 'spreading rumours' from some readers, media commentators and high-

83 'Netto kōsaku-in no seitai (Truth About Net Managers)', 16 September 2014, ameblo. jp/64152966/entry-11925550749.html. Accessed 1 August 2015.

84 The class action also intends to prove that up to 70,000 American citizens were exposed to radiation from Fukushima Daiichi. See Charles Bonner, lawyer for the USS Ronald Reagan class action plaintiffs, www.youtube.com/watch?v=V0zGbG2dTvo.

85 See non-government organisation founder of Social Uplift and journalist, and personal friend of Iwaji, Beverly Findlay-Kaneko at 12-17.45 mins. on Nuclear Hotseat, 16 September 2014, nuclearhotseat.com/2014/09/13/nuclear-hotseat-169-beverly-findlay-kaneko-on-journalist-iwajisdeath-karl-grossman-on-nukes-in-space/. See also Beverly Kaneko-Findlay, 'Update on Fukushima', 14 September 2014, www.youtube.com/watch?v=xm2oibl00ie. See also Imanishi Noriyuki, 'Asahi TV Rage: Big Battle with Police at the Shoddy Decontamination Interview Site', 21 December 2013, www.imanishinoriyuki.jp/archives/35811450.html. 
level politicians. Similarly, Takenouchi Mari, a freelance journalist and mother who evacuated from Fukushima in 2011, received thousands of slanderous messages and threats to her two-year-old son and her property after criticising the co-founder of Fukushima ETHOS on her blog in mid-2012. She too reported that her internet account was suspended and her request for a police investigation ignored. She was counter-sued for harassment and subjected to a criminal investigation and civil law suit. ${ }^{86}$

Among the activists who have been arrested for anti-nuclear protests, the academic Shimoji Masaki of Hannan University (9 December 2012) was arrested by Osaka Prefectural Police and charged with 'violating the Railway Operation Act' for walking through an Osaka station concourse while participating in a demonstration against radioactive waste incineration (17 October 2012). Shimoji had reiterated that residents, due to radioactive incineration (which was due to commence in Osaka in February 2013), would be forced to bear the burden of air, food and water contamination. ${ }^{87}$

Despite such obstacles to developing a political consciousness as well as the obvious difficulties in permanently resettling large populations, it has been not only evacuees who have had to think about their fundamental life priorities after the Fukushima Daiichi nuclear distaster. Some have adopted real (not only psychological) self-protection mechanisms. The voluntary Fukushima Collective Health Clinic (Fukushima Kyödō Shinryojo 福島共同診療所), for example, is founded on three principles: respite (hoyō 保養), treatment (shinryō 診療) and healing (iryō 医療). Co-founder Dr Sugii, advocates a return to the $1 \mathrm{mSv} / \mathrm{y}$ limit, and seeks to inform those who for whatever reason cannot move from contaminated areas in Fukushima Prefecture. ${ }^{88}$ This is modelled on Belrad, the independent health clinic in Belarus run by Alexey Nesterenko, which prioritises knowledge, safety and open information on radiation and its health impacts.

86 Takenouchi Mari, '2nd Consultation to Kyoto Bar', April 2014, accessed 1 July 2015, savekidsjapan.blogspot.jp/2014/04/2nd-consulation-to-kyoto-bar.html.

87 Shimoji Masaki, 'Demand for the immediate and unconditional release of Associate Prof. Masaki Shimoji', Civic Activity - an Organization Supporting Citizens Opposing Spread of Radiation, 15 December 2012, keepcivicactivity.jimdo.com/english/. See also, 'Press Conference for the Apology and Immediate Release of Professor Masaki Shimoji and other People Unjustly Arrested for Opposing Debris Incineration in Osaka', 15 December 2012, iwj.co.jp/wj/open/archives/46334; 'Statement from Mr. Shimoji during unjust detention', 13 December 2012, goo.ne.jp/garekitaiho1113/e/79c68fd 4e86da4ec02b2e01a5188052b.

88 Dr Sugii, interview with the author, digital audio recording, 24 March 2015. 
To counteract the misinformation residents were exposed to postChernobyl, over time and with limited resources, Belrad and other organisations have disseminated information and organised respite trips for children in affected areas. In 2015, for example, subsidised respite trips were organised for 50,000 children, and results have shown that over two continuous years of respite those who accumulated 25$35 \mathrm{~Bq} / \mathrm{kg}$ had reduced the amount to $0 \mathrm{~Bq} / \mathrm{kg}$. Unlike the flat limit of $100 \mathrm{~Bq} / \mathrm{kg}$ of Caesium in food in Japan $(50 \mathrm{~Bq} / \mathrm{kg}$ for milk and infant foods, $10 \mathrm{~Bq} / \mathrm{kg}$ for drinking water), Belrad recommends an internal radiation limit of $10-30 \mathrm{~Bq} / \mathrm{kg}$ in the body (although it advises below $10 \mathrm{~Bq}$ for infants to avoid lesions and heart irregularities) ${ }^{89}$ It should be noted that these limits do not guarantee safety against the effects of repeating internal radiation exposure from consuming contaminated foods, which is relative to the length of time the radiation remains and its location in the body.

While some communities, such as the town of Aketo in Tanohama, Iwate Prefecture, have struggled to block the siting of nuclear waste storage facilities, ${ }^{90}$ others are also organising to reduce radio-accumulation in their children through respite trips, ${ }^{91}$ as well as concentrating on indoor activities, measuring hotspots and decontaminating public areas and pathways, pooling funds for expensive spectrometers to monitor internal exposure and food and water, incorporating dietary radioprotection, as well as finding ways to reduce anxiety.

Many local farmers cannot admit the already near-permanent damage to their land (which may continue for hundreds of years) because it would imply the devaluation of their property and produce as well as threatening their ancestral ties to the land, commitments and future plans. While many are keenly aware of their responsibilities, the push by the Fukushima and central governments to identify and gain access to markets for produce from irradiated areas would make it easier to overlook uncomfortable factors. Some have argued that given the reassurances of safety from the highest authorities, these offical figures should therefore relocate to

89 See Kamanaka Hitomi, Canon Dayori, vol. 4 (2015) (Independent DVD documentary, dir. Kamanaka Hitomi).

90 Toshihide Ueda, 'Women in Tohoku Village Refused to Play Host to Nuclear Plant', Asahi Shimbun, 2 September 2015, ajw.asahi.com/article/views/column/aj201509020011. Since the time of writing, this link is no longer available. For verification, an online mirror link can be found at: www.fukushima-is-still-news.com/2015/09/tanohata-women-against-nukes.html.

91 Sasaki Michinori (38 years old) in Fukushima Radiation, 848. 
contaminated areas and consume these products regularly. Despite the fairness of this statement, a more utilitarian logic has prevailed. In the name of reconstruction and revitalisation of Fukushima and the nation, the dilution of Fukushima produce with unirradiated produce to return measurements just under the required limits, radiation spikes in soil and food or the mutation of plants as Caesium replaces potassium (K40), for example, tend to be minimised. In this climate, the distribution and relabelling of Fukushima produce for urban and international markets (i.e. in a black market of cut-price bulk produce picked up by yakuza and other brokers) is likely to continue.

To date, the majority of evacuees have refused to return to (de)contaminated areas. Some claim they are yet to receive accurate information to justify it. Independent specialists such as Hosokawa Kōmei (Citizens' Commission on Nuclear Energy), who develops models for transition to renewable alternatives, anticipate an increase in evacuee populations as they predict increased resettlement of Fukushima residents over $20-30$ years. ${ }^{92}$ As some evacuees recognise the potential for second or third Fukushimas, they have sought to strengthen their collective identities and rights. Through local organisation and alternative life practices, whether in micro-scale ecovillages and transition towns ${ }^{93}$ with communal occupancies and squats, parallel currencies and local exchange systems (roughly 70 substantive projects), organic food co-ops, self-sufficient energy systems, local production and recycling, carpools and free kindergartens, such groups are seeking to reconstruct and model core social priorities, focusing on clean food, health and community cooperation rather than the internalised and dreary competition for material accumulation.

Although the accountability of authorities with prior knowledge has yet to be properly investigated, one of the largest groups of collective legal actions to be mounted in Japanese history includes some 20 lawsuits by 10,000 plaintiffs. The Fukushima genpatsu kokuso-dan (Group of Plaintiffs for Criminal Prosecution 福島原発告訴団), formed on 20 April 2012, filed a criminal case (lodged 3 September 2013, Fukushima District Court) against 33 previous and present officers of TEPCO, government officials and medical experts for 'group irresponsibility' and the neglect of duty of care, environmental damage and harm to human health. Mutō Ruiko, one of the key plaintiffs, declared the main aim to be

92 Hosokawa Kōmei, interview with the author, digital audio recording, 30 March 2015.

93 Uno Saeko in Kamanaka, Canon Dayori. 
symbolic: to publicly record injury, reclaim the victims' sense of agency and protect the next generation. In short, they were seeking recognition of wrong and harm done rather than primarily financial redress. This moderate aim was undoubtedly tempered by recognition of regulatory capture: those who were cavalier with safety procedures 'were now in charge of restarts; those responsible for the "safety" campaign were now in charge of the Health Survey; [there has been] no responsibility for the SPEEDI cover-up; and TEPCO is not being held responsible for [faulty] decontamination'. ${ }^{94}$

The judgement of this case was handed down at the Tokyo District Court on the same day as the announcement of Tokyo's successful Olympics bid (9 September 2013). The case was dismissed on the grounds that the disaster was beyond predictability (sōteigai 想定外), which made negligence hypothetical. ${ }^{95} \mathrm{~A}$ citizens' panel (Committee for inquest of Prosecution) overturned the dismissal and renewed the claim against three TEPCO executives on 18 December 2013. They demanded, alongside a ruling of negligence against three former TEPCO executives, the inclusion of physical, economic, social and psychological harms: illness, paediatric underdevelopment (radiation exposures, excessive isolation indoors), financial losses (unemployment, loss in property value, rental costs of two homes, relocation, travel, etc.), family and community division, ijime (bullying いじめ) and stress. Many plaintiffs also claimed that their disrupted reliance upon nature, ${ }^{96}$ as inviolable and precious, ${ }^{97}$ should be recognised as harm. This too was dismissed and again a citizen's panel found against the three TEPCO executives. ${ }^{98}$ In May 2015, 10 groups of plaintiffs formed a network named Hidanren (被弾連, Genpatsu Jiko Higaisha Dantai Renrakukai) comprising 20,000 people. The Fukushima kokuso-dan again made a claim to another citizens' panel, which found in

\footnotetext{
94 Mutō Ruiko, Fukushima Radiation, 268.

95 Hamada Kentaro, 'Fukushima Operator's Mounting Legal Woes to Fuel Nuclear Opposition', Reuters, 17 August 2015, uk.reuters.com/article/japan-nuclear-tepco-legalidUKL3N10E2G820150817. Accessed 17 August 2015.

96 Asada Mariko (63 years old), 27 April 2012, Fukushima Radiation, 303.

97 Furukawa Machiko (64 years old), 1 June 2012, Fukushima Radiation, 400.

98 Editors, 'Indictment of TEPCO trio encourages Fukushima nuclear accident victims', Asahi Shimbun, 1 August 2015, ajw.asahi.com/article/0311disaster/fukushima/aj201508010032. Since the time of writing, this link is no longer available. For verification, an online mirror link can be found at: www.fukushima-is-still-news.com/2015/08/teoco-s-indictment-a-sense-of-justice.html. Yayoi Hitomi (54 years old), 11 May 2012, Fukushima Radiation, 343; Matsutaka Chiwaki (41 years old), 8 June 2014, Fukushima Radiation, 343.
} 
July 2015 in favour of indicting the three TEPCO executives for trial. ${ }^{99}$ In addition, a civil case filed in June 2015 by 4,000 plaintiffs from Iwaki seeking to prove negligence and not just harm sought to use previously withheld evidence to show fair warning of a 3.11-type scenario was given. This case focused the court on the operator's calculation of risk probability of a tsunami of that size and, rather than aiming at financial compensation, it sought to deter nuclear operators from future negligent practices if ruled in favour. In anticipation of out-of-court settlements, the Japanese Government increased the budget for compensation payments to 7 trillion yen (US\$56 billion).

\section{Conclusions}

From this discussion, it is evident how an advanced capitalist nation-state deploys a disposable population of informal labour to absorb the dangers inherent to the use of large-scale nuclear technologies and its private extractive and accumulation practices. Since its inception, nuclear power has been regarded by some as a symbol of Japan's postwar civilisational progress. ${ }^{100}$ At the same time, the health of many thousands of people has been endangered in exposures to radiation while harms have been perpetrated upon local communities and nuclear workers and the environment more broadly as millions of people have been integrated within the centralising and concentrating dynamic of the transnational nuclear power industry.

On the mediated surface, Fukushima Daiichi has been used to prove to the world that a nuclear disaster of significant scale can be overcome and that people can survive and return to their normal lives. The government has concentrated on proving that it is safe for the Olympics, safe for tourism, safe to consume local produce, and safe to restart nuclear reactors (with 25 reactors expected to be supplying 20 per cent total energy by 2030). The neoliberal disaster model adopted, in which the state prioritises the profit of private corporations and their wealth-creating strategies while

99 For more on this see Norma Field, 'From Fukushima: To Despair Properly, to Find the Next Step', The Asia-Pacific Journal: Japan Focus 14, issue 11, no. 3, September 2016.

100 Kasai Yoshiyuki, Chairman of Central Japan Railways, described nuclear power as the nation's 'bloodstream of economic activity' and the only way to obtain sustainable baseload electric power. Kasai Yoshiyuki, 'Nuclear Energy is Indispensable for Japan's Future', November, Association of Japanese Institutes of Strategic Studies, Commentary No. 165, 2012, www.jiia.or.jp/en/ commentary/201211/13-1.html. Accessed March 2014. 
minimising public services and pursuing deregulation (e.g. of labour conditions), is indicated not only in the official intention to rebuild the local economy of Fukushima Prefecture, but also to expand, including through its transnational nuclear industry, Japan's financial, military and industrial sector after Fukushima. This reflects the priority given to both the interests of the utilities, banks and construction companies involved in the reconstruction program, and those of multinational corporations, foreign governments and international regulatory and financial institutions involved in this sector.

At the same time, the sovereign duty to protect the fundamental needs of the population and reflect majority will is secondary to these priorities. Unlike a natural disaster, owing to the materiality of radiation that continues to be dumped and vented into the environment, facilitating the return to pre-disaster conditions by forgetting and rebuilding communities in contaminated areas is a practice of illusion. Despite the claims of the Abe administration and other nuclear promoters, Japan's safety standards cannot adequately insure against the seismic activities or extreme weather events and their impacts on that archipelago. The authorities have furnished people with the means by which to normalise sickness and pathologise anxiety to justify the return to nuclear power reliance, while suppressing those who seek to resist it. The wealth of a healthy society and environment cannot be traded for the putative convenience and economic benefits of nuclear power generation as they are not comparable values. Official denial of the steady accumulation and exposure to 'low-level' internal radiation in a growing segment of the population only aggravates rather than protects the affected communities from the stresses related to Fukushima Daiichi. This inescapably leads to the need to address greater systemic problems that underlie such disasters.

As the previous organic life of village communities in contaminated zones is transformed into retirement villages and ad-hoc industrial hubs for temporary workers, this alienation from food, land, community, history, the human body and nature itself is a warning of the growing negative costs of the rapid expropriation and consumption of the planetary commons under a globalised system. Just as nuclear energy is not the solution to climate disruption caused by reliance on fossil fuels in a global capitalist economy, nor are radiation exposures comparable to everyday risks in modern society (i.e. transport accidents). If introducing 'mistakes' into the human genome is to be wagered against the daily conveniences of 'modern' life then this aspect of modernity is unsustainable. Although 
somewhat anthropocentric, it is a timely reminder that the Nobel Prize laureate (1946) Herman Müller stated in 1956, 'the genome is the most valuable treasure of humankind. It determines the life of our descendants and the harmonious development of the future generations'. ${ }^{101}$

And so we return to the basic problem that no nuclear reactor can operate without radiation-exposed labour, particularly of informal or irregular workers. If these populations refused to work and joined in support with a network of translocal groups on informal and alternative life projects for greater self-sufficiency such as micro-financing, small-scale and permaculture farming on non-contaminated land, renewable and decentralised energy production and distribution, or campaigns for greater distribution of wealth, better public education and health improvement, these communities and workers could be active agents in devising models that could eventually become viable for adaptation to larger human populations. This application at scale cannot come too soon in the present context of imminent exhaustion of the planetary commons from the systemic demands for relentless economic growth and accumulation of wealth and power for the few.

\section{Acknowledgement}

Research for this chapter was made possible by the author's ARC DECRA project, 'Contaminated Life: 'Hibakusha' in Japan in the Nuclear Age' (DE130101746).

101 Herman Müller, 'Radiation and Heredity', American Journal of Public Health 54, no. 1 (1964): $42-50$. 
This text is taken from New Worlds from Below: Informal life politics and grassroots action in twenty-first-century Northeast Asia, edited by Tessa Morris-Suzuki and Eun Jeong Soh, published 2017 by ANU Press, The Australian National University, Canberra, Australia. 